\title{
Public Attitudes towards Fast Fashion
}

\section{Phakawan Teerawattananon ${ }^{1}$, Phatsa Khuanpad ${ }^{2}$, Renuka Hitopakorn ${ }^{3}$, Varitsara Lapkritkhom ${ }^{4}$, Watusiri Limwattana ${ }^{5}$}

\author{
${ }^{1}$ Hatyaiwittayalai School, Songkhla, Thailand, ${ }^{2}$ Bangbowitthayakhom School, Samut Prakan, Thailand \\ ${ }^{3}$ Kajonkietsuksa School, Phuket, Thailand, ${ }^{4}$ Hatyaiwittayalai2 School, Songkhla, Thailand \\ ${ }^{5}$ Princess Chulabhorn Science High School Mukdahan, Mukdahan, Thailand
}

Corresponding Author: Watusiri Limwattana

\begin{abstract}
Fast fashion is a fashion product that is rapidly producing according to the fashion trends. It isn't durable and people worn them a few times before being discarded, which turned them into a lot of garbage. It dyed with fabric dyes and chemicals that used in its production. This might have a big impact on the health of the wearer and the manufacturer. Especially, it also impacts on the environment in many ways. The purpose of this study is to explore the attitude and accessibility of fast fashion in each generation to realize the impact and problems of fast fashion. Additionally, we study people's motivation and factors in purchasing clothes. This research shows an analytical survey, it was conducted to survey 510 individuals in each generation. The survey was conducted by Google form survey. This survey found that the mostly respondents had third level of awareness of fast fashion issues, most of them are gen $y$ and $\mathrm{z}$ and they still buy fast fashion products. A few people aware about this issues and support reducing the use of fast fashion products. If this situation continues, it will lead to a lot of unusable waste which is difficult to eliminate by incineration. This will lead to the production of many chemicals used in production to float up and destroy the atmosphere. It also causes air pollution problem to the surrounding area. Therefore, it can only be piled together to accumulate waste and the number of wastes multiplied over the years.
\end{abstract}

Keywords: Fast fashion; Attitudes; Generation

\section{INTRODUCTION}

Fast fashion means clothes and fashion items that are produced rapidly at the lowest prices. While the demands of buyers are very high and wear them a few times, then throw away and buy a new one instead. However, the increasing demands resulting from fast fashion has a negative impact on the environment. Disadvantages of fast fashion are affected to the people can be devided into three ways: ${ }^{[4]}$

\section{Negative effects on the health of the wearer}

Most fashion garments are made of polyester. It's the plastic and a cheap product. Every time when we wash a shirt that made of polyester, it could release of microplastics from synthetic clothes. Water can be contaminated in several ways from water washing. When that water enters a natural water source, sea animals that living under water use water for their livelihood. Also, humans who eat sea food then Microplastics in sea animals can be harmful to their health.

\section{Negative effects on the health of the manufacturer}

Manufacturer in this research, we don't mention to capitalists, but it means workers. The labor, who are working with clothing and fashion machinery are mainly produced from third world countries such as Bangladesh, Indonesia, and Sri Lanka. Because that countries were one of the lowest labor costs. These countries don't 
have many job options. Workers in some countries are forced to work for 18 hours a day, without holidays and earns a salary of about 1000 baht. Many of these workers often ill and die of lung disease. Cancer caused by the accumulation of chemicals used to make fabrics. At present, there are more girls around the world, 170 million people are the victims of forced labor of fast fashion garment manufacturing.

\section{Negative effects on the environment}

With 18.6 million tons of clothes per year, these garments are buried at landfill. $73 \%$ of all discarded clothing will be cremated or buried. While only $12 \%$ are recycled into other products. Less than $1 \%$ are recycled into new clothes. It is expected that this year, there will be 18.6 million tons of clothing that will eventually end up in landfill and the amount of waste generated by discarded clothing. Clothing production also affects the environment due to the amount of water required. And the wastewater generated by the manufacturing process, including the effects of dyes on water pollution. In addition, the production of garments using various synthetic fibers. Either nylon or polyester, it affects the generation of greenhouse gases emission.

This shows that fast fashion has a huge impact on the environment. What should do it now is to reduce the use of fashion.

Fashion trends have long played a role in the dress behavior of people around the world. It is a trend that is created and encourages the purchase of new clothes to meet the endless consumer demand. Even fashionably dressed in their own style creates a lively color for both the wearer and the everyone who sees their dress, but on the other hand the world of clothing is also constantly being asked for environmental responsibility. Especially, when this industry is identified as it is the second most polluting in the world after the oil industry and most importantly is creating a huge waste problem. The success of the fashion industry, it makes the global clothing industry developed rapidly. Currently, they are more than 150 billion pieces of clothes per year. Disposal also creates a burden and impact on the environment.

This research is an analytical survey research on people's attitudes towards fast fashion. It determine how people have attitudes on it, recognizing the problems, impacts of fast fashion, how to change your clothing habits and how to deal with them. To reduce the use of fast fashion, it doesn't affect on people in each generation. So that people in each generation are aware of the influence and problems of fast fashion, to study the motivations and factors in buying clothes.

\section{MATERIALS \& METHODS}

\section{Population and samples}

The population is Gen $\mathrm{Z}$ (under 23 years old) 375 people, Gen Y (23-40 years old) 77 people, Gen X (41-55 years old) 43 people and Baby Boomers (56-74 years old) 15 people.

The sample group used in this research was a questionnaire and respondents categorized by Generation, which received a total sample of 510 respondents.

\section{Research tools}

The research tool was an online survey on attitudes towards Fast fashion. The question was chosen based on the respondents' habits of Fast fashion and buying clothes.

\section{Data Collection}

The methods of collecting data from the sample are as follows:

1. Researchers gather infographic to introduce Fast fashion for respondents to read and understand before answering.

2. The researcher conducted an online questionnaire to all 510 respondents.

\section{Statistical Analysis}

Analysis of personal data of the respondents and analyze what the respondents choose to answer by using descriptive statistics, i.e., percentage. 


\section{RESULT}

Level 0 Unawareness

It refers the person who answers, there is no awareness of the problems of fast fashion, with 6 out of 510 respondents, or $1.2 \%$.

Level 1 very little awareness. This referrs that the respondents have a very little awareness, there were 22 of 510 respondents, or $4.3 \%$.

Level 2 little awareness. This refers the respondents have less awareness. There were 164 out of 510 respondents, representing $32.2 \%$.

Level 3 intermediate consciousness. It refers that the respondents are aware of the middle end. There were 216 out of 510 respondents, or $42.4 \%$.

Level 4 very aware. It refers to the person who responded with a lot of awareness. There were 102 respondents out of 510 people, representing $20 \%$.

Table 1: Are you aware about effect of Fast fashion?
\begin{tabular}{|c|c|c|}
\hline Level & Number & Percentage \\
\hline 0 & 6 & 1.2 \\
\hline 1 & 22 & 4.3 \\
\hline 2 & 164 & 32.2 \\
\hline 3 & 216 & 42.4 \\
\hline 4 & 102 & 20 \\
\hline
\end{tabular}

Table 2: Do you agree in avoiding Fast fashion?

\begin{tabular}{|l|c|c|}
\hline \multicolumn{1}{|c|}{ Notion } & Number & Percentage \\
\hline Strongly agree & 50 & 9.8 \\
\hline Agree & 287 & 56.3 \\
\hline Neither agree or not disagree & 37 & 7.3 \\
\hline Disagree & 130 & 25.5 \\
\hline Strongly disagree & 6 & 1.2 \\
\hline
\end{tabular}

Strongly agree, there were those who responded with their opinion that Strongly agree to reduce the use of fast fashion by $35.3 \%$.

Agree, there are people who answer with their opinions. Strongly agree to reduce the use of fast fashion $56.3 \%$.

Neither agree or not disagree, it means disagree. Some respondents disagree in reducing the use of fast fashion $7.3 \%$.

Strongly disagree, there were those who responded with their opinion that Strongly opposed to reducing the use of fast fashion $1.1 \%$.
Table 3: Are you aware of social and Environmental impacts of Fast fashion?

\begin{tabular}{|c|c|c|}
\hline Answer & Number & Percentage \\
\hline Yes & 421 & 82.5 \\
\hline No & 16 & 3.1 \\
\hline Maybe & 73 & 14.3 \\
\hline
\end{tabular}

-yes/aware, it means respondents have a deep knowledge and understanding of fast fashion.

-no/not aware, it means the respondent has no knowledge and understanding of fast fashion.

-maybe/not sure, this means that respondents may have heard or known about fast fashion but didn't understand the information clearly.

Table 4: Number and percentage of respondents by gender
\begin{tabular}{|c|c|c|}
\hline Gender & Number & Percentage \\
\hline Male & 96 & 18.8 \\
\hline Female & 368 & 72.2 \\
\hline N/A & 46 & 9 \\
\hline
\end{tabular}

-Male refers to the respondents who have a masculine gender.

-Female refers to the respondent, who is a female gender.

-Unspecified refers to those who don't want to specify their gender, so it mark as Sexuality.

Table 5: Number and percentage of respondents by age

\begin{tabular}{|l|c|c|}
\hline \multicolumn{1}{|c|}{ Age } & Number & Percentage \\
\hline Gen Z & 375 & 73.5 \\
\hline Gen Y & 77 & 15.1 \\
\hline Gen X & 43 & 8.4 \\
\hline Baby Boomer & 15 & 2.9 \\
\hline
\end{tabular}

Table 6: How often do you go to shopping?

\begin{tabular}{|l|c|c|}
\hline \multicolumn{1}{|c|}{ Frequency } & Number & Percentage \\
\hline Everyday & 1 & 0.2 \\
\hline Once a week & 41 & 8 \\
\hline Less than one time in three months & 235 & 46.1 \\
\hline One time a month & 160 & 31.4 \\
\hline More than one time a month & 73 & 14.3 \\
\hline
\end{tabular}

Population Segmentation according to Economist concepts can be divided as follows

First group is Baby Boomer In other words, they are elderly group, which is a group of people aged 54-72 years.

The second group is Gen $\mathbf{X}$ which is the group of people, 38-53 years old.

The third group is Gen $\mathbf{Y}, 21-37$ years old. The fourth group is Gen Z, 8-20 years old. 
Table 7: Which shops do you visit most frequently when you purchase apparel?

\begin{tabular}{|l|c|c|}
\hline \multicolumn{1}{|c|}{ Shop } & Number & Percentage \\
\hline Brand (H\&M, Uniqlo, ZARA etc.) & 285 & 55.9 \\
\hline Second-hand store & 146 & 28.6 \\
\hline Market, Night market & 227 & 44.5 \\
\hline $\begin{array}{l}\text { Online store (Shoppee, } \\
\text { SHEIN, IG,Facebook etc.) }\end{array}$ & 290 & 56.9 \\
\hline Luxury brands & 35 & 6.9 \\
\hline
\end{tabular}

Table 8: What are the reasons that effects your decision of purchasing clothing items?

\begin{tabular}{|l|c|c|}
\hline \multicolumn{1}{|c|}{ Reason } & Number & Percentage \\
\hline Price & 414 & 81.2 \\
\hline Design & 423 & 82.9 \\
\hline Source & 64 & 12.5 \\
\hline Environmental impact & 82 & 16.1 \\
\hline School/Workplace trend & 57 & 11.2 \\
\hline Social media trend & 100 & 19.6 \\
\hline Quality & 364 & 71.4 \\
\hline Morality & 63 & 12.4 \\
\hline Brand & 166 & 32.5 \\
\hline Suggestion & 68 & 13.3 \\
\hline Influencer & 55 & 10.8 \\
\hline Fondness & 2 & 0.4 \\
\hline Trend & 1 & 0.2 \\
\hline Can mix and match for many looks & 1 & 0.2 \\
\hline Dressing preference & 1 & 0.2 \\
\hline Personal preference & 1 & 0.2 \\
\hline Can reuse it & 1 & 0.2 \\
\hline Texture & 1 & 0.2 \\
\hline Confidence & 1 & 0.2 \\
\hline All of them & 1 & 0.2 \\
\hline Taste & 1 & 0.2 \\
\hline
\end{tabular}

H\&M, Uniqlo, ZARA Brands etc. It refers to different brands of clothing are sold in department stores and are very popular with buyers.

Second-hand store It refers to clothes that have been used before but still in good like new and usable and it's cheaper than new clothes.

Market, Night market It refers to clothes that we can be purchased at the flea market or night market.

Online store (Shoppee, SHEIN, IG, Facebook etc) It refers to the online shopping application is considered for trading products between entrepreneurs and customers. which is an online media system, that is a website and a trading management system. The customers always buy goods and services from that operator

Luxury brands It refers to clothing that is luxury, good quality, high prices and has a great customers base.
Table 9: When you want to get rid of a piece of clothing, what do you do with it?

\begin{tabular}{|l|c|c|}
\hline \multicolumn{1}{|c|}{ Answer } & Number & Percentage \\
\hline Keep it anyway & 213 & 41.8 \\
\hline Throw it away & 42 & 8.2 \\
\hline Handover & 435 & 85.3 \\
\hline Fix it/recycle it into something new & 136 & 26.7 \\
\hline Sell it & 101 & 19.8 \\
\hline
\end{tabular}

Price It refers to price of clothes (Respondents accounted for $81.2 \%$ of the total).

Design Clothing has been designed into various forms (Respondents accounted for $82.9 \%$ of the total).

Source It refers to place for clothing production (Respondents accounted for $12.5 \%$ of the total).

Environmental impact How does the clothing affect to the environment? (Respondents accounted for $16.1 \%$ of the total).

School/Workplace trend It refers to that most people in school or in the workplace who wears that style of clothing (Respondents accounted for $11.2 \%$ of the total).

Social media trend The style of clothing that most people on social media love wearing them. (Respondents accounted for $19.6 \%$ of the total)

Quality The durability of clothing and the use of good materials in clothing production (The respondents accounted for $71.4 \%$ of the total).

Morality Clothing that is produced by followed the ethical manner (Respondents accounted for $12.4 \%$ of the total).

Brand Various brands of clothing (Respondents accounted for $32.5 \%$ of the total)

Suggestion It refers that we always buy clothes from other people's suggestions (Respondents accounted for $13.3 \%$ of the total).

Influencer (celebeauty, actor, Influencer etc) Purchasing clothes based on social media influencer's recommendations (Respondents accounted for $10.8 \%$ of the total) 
Table 10: "I like it, I buy it ", "I want it, I got it" describes my behavior in Fast fashion retail environments

\begin{tabular}{|l|c|c|}
\hline \multicolumn{1}{|c|}{ Notion } & Number & Percentage \\
\hline Strongly agree & 38 & 7.5 \\
\hline Agree & 93 & 18.2 \\
\hline Neither agree nor disagree & 226 & 44.3 \\
\hline Disagree & 131 & 25.7 \\
\hline Strongly disagree & 22 & 4.3 \\
\hline
\end{tabular}

Table 11: Have you ever bought an item of clothing and not worn it?

\begin{tabular}{|c|c|c|}
\hline Answer & Number & Percentage \\
\hline Yes & 337 & 66.1 \\
\hline No & 173 & 33.9 \\
\hline
\end{tabular}

\section{CONCLUSION}

From this analytical survey, target audience of 510 people, they have a level 3 awareness. This means that 216 of the 510 respondents had moderate awareness, or $42.4 \%$. They agreed to reduce their use of fast fashion. Most respondents tend to buy clothes less than once in three months, which is $46.1 \%$ of the total number of respondents. The purchasing factors of buyers are price, design, and product quality. The most popular places for clothing by respondents were online shopping application and brand stores, accounting for $56.9 \%$ and $55.9 \%$, respectively. According to the survey, the most common way respondents doing with their used clothing is by handing them over and donating them, which accounted for $85.3 \%$.

Although many people understand this problem. But only a few people are aware with them. If this situation continues, it will lead to create a large amount of unusable waste. It's difficult to eliminate them by incineration. This will lead to the chemicals used in production, it floats up and destroy the atmosphere. It also causes air pollution to the surrounding area. Therefore, it can only be piled together as garbage accumulated, which is multiplied in every year. From this survey, reducing the use of fast fashion can be done by reuse clothes. We can campaign for Fast Fashion by reducing our purchasing, focusing on quality clothing, buy second-hand clothes, avoiding Fast Fashion, providing rental services for many people, taking the photos of check-in in various places on social media, supporting Eco Friendly brands and changing from Fast Fashion to Eco fashion. The short meaning of "Eco fashion" is environmentally friendly, including nature, animals, and humans, etc.

To conclude the target audience, It is aware of Fast fashion in moderate level and agree to reduce their use. Nowadays, people still don't have much access to Fast fashion. But when they consider the problems behind fast fashion, they will have their own opinions to reduce their use, which satisfies the premise. ${ }^{[11]}$

\section{Acknowledgement: None}

Conflict of Interest: None

\section{Source of Funding: None}

\section{REFERENCES}

1. Chanwatcharachot, T. (2020, August 24). ผ้าโพลีเอสเตอร์ คืออะไร มีคุณสมบัติอะไรบ้าง. mcshop. www.mcshop.com/blog/t-shirts.

2. Chatuchinda, Supang. “ตีแผ่ความจริงของมลพิษใน Fast Fashion." Greenpeace Thailand, 12 Mar. 2019, www.greenpeace.org/thailand/story/4704/fa st-fashion-toxic/.

3. Chec, Commonwealth Human Ecology Council. "Clothing Waste and Fast Fashion in 2020." CHEC International, 25 May 2021, www.checinternational.org/clothingwaste-and-fast-fashion-in-2020/.

4. Chinasamy, J. (2019, October 21). Fast fashion อุตสาหกรรมตัวร้าย: แฟชั่นติดไซเรน. www.greenpeace.org/ thailand/story/9381/fast-facts-about-fastfashion/.

5. Koh, H. (2017, October 4). A way to repeatedly recycle polyester has just been discovered. www.eco-business.com/news/away-to-repeatedly-recycle-polyester-hasjust-been-discovered.

6. Niinimäki, Kirsi, et al. "The Environmental Price of Fast Fashion." Nature News, Nature Publishing Group, 7 Apr. 2020, www.nature.com/articles/s43017-020-00399.

7. Pim, P. (2019, March 4). Fabscrap ทางออกหนึ่งของปัญหาขยะผ้า ในมหานครแห่งแฟชั่น. www.greenery.org/articles/wastesidestoryfabscrap/. 
8. Sugg, Liz. "It's Time to Break down the Fast Fashion Industry: The Wellesley News." The Wellesley News |, The Student Newspaper of Wellesley College, 29 Mar. 2021, thewellesleynews.com/2021/03/28/its-timeto-break-down-the-fast-fashion-industry/.

9. ThaiPBS. (2021, January 8). Fast fashion แฟชั่นทำลายโลก: พื้นที่ชีวิต (8 ม.ค. 64). YouTube. www.youtube.com/watch?v= lhqFQ3nfUo4.

10. ปัญหาของ fast fashion [Internet]. springnews. springnews; 2021 [cited 2021Aug23].
Available

from:

www.springnews.co.th/spring-life/805941

11. ทีมข่าวการเปลี่ยนแปลงสภาพภูมิอากาศ

ทีมข่าวการเปลี่ยนแปลงสภาพภูมิอากาศ. '“Fast Fashion' ซื้อง่าย-หน่ายเร็ว ผลิตมาก-ราคาถูก-สูบทรัพยากรโลก." สำนักข่าวสิ่งแวดล้อม (GreenNews), $17 \mathrm{Apr}$. 2018, greennews.agency/?p=16754 .

How to cite this article: Teerawattananon $\mathrm{P}$, Khuanpad P, Hitopakorn R et.al. Public attitudes towards fast fashion. International Journal of Research and Review. 2021; 8(9): 378-383. DOI: https://doi.org/10.52403/ijrr.20210949 